\title{
Corrigendum: Growth of semiconducting single-wall carbon nanotubes with a narrow band-gap distribution
}

Feng Zhang, Peng-Xiang Hou, Chang Liu, Bing-Wei Wang, Hua Jiang, Mao-Lin Chen, Dong-Ming Sun, Jin-Cheng Li, Hong-Tao Cong, Esko I. Kauppinen \& Hui-Ming Cheng

Nature Communications 7:11160 doi: 10.1038/ncomms11160 (2016); Published 30 Mar 2016; Updated 27 Apr 2016

This Article contains an error in Fig. 6. In Fig. 6a, the units on the y-axis should be ' $\mu A^{\prime}$ not ' $m A$ '.

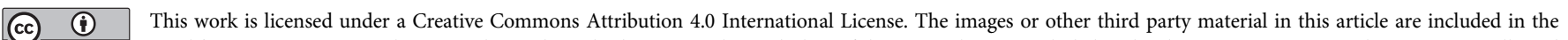
article's Creative Commons license, unless indicated otherwise in the credit line; if the material is not included under the Creative Commons license, users will need to obtain permission from the license holder to reproduce the material. To view a copy of this license, visit http://creativecommons.org/licenses/by/4.0/ 